\title{
ЗАСТОСУВАННЯ СИСТЕМНОГО ПІДХОДУ ДЛЯ ПОБУДОВИ ОРГАНІЗАЦІЙНОЇ СТРУКТУРИ УПРАВЛІННЯ ПІДПРИСМСТВОМ
}

DOI: $10.32620 /$ cher.2020.4.11

Постановка проблеми. Розглядаються питання щодо проектування організаційної структури управління підприємством у процесі його реструктуризації. Метою статті є розгляд сутності реструктуризації підприємства як однієї з причин необхідності організаційних перетворень у компанії та розроблення практичних рекомендацій щодо застосування теорії системного аналізу для побудови раціональної організаційної структури управління підприємством. Методологічною основою дослідження стали логічні методи обробки інформації, методи системного аналізу та моделювання систем, абстрактно-логічний метод для формулювання висновків. Основна гіпотеза дослідження полягає в тому, що для побудови ефективної організаційної структури управління підприємством можна використовувати методи системного аналізу, зокрема процесний та системний підхід. Виклад основного матеріалу. Розглянуто сутність та причини необхідності структурних перетворень в організації. Виявлено, що діяльність будь-якої організації піддається впливу постійно змінюваного внутрішнього і зовнішнього середовища. Це вимагає від керівництва підприємства швидкого реагування та адаптації до нових умов функціонування. Гнучкість, адаптивність, стійкість функціонування системи управління, а також узгодженість поведінки всіх ііі елементів, забезпечення раціонального поєднання централізації i децентралізації управління залежать від організаційної структури управління підприємством. Запропоновано комплекс взаємозалежних моделей системи управління підприємством, використання якого дасть змогу спроектувати організаційну структуру, здатну врахувати визначені вимоги. Оригінальність та практична значимість дослідження підтверджується можливістю використання запропонованого комплексу моделей як практичного інструмента для проектування організаційної структури підприємства будь-якого типу. Запропоновані розробки можуть бути використані як елемент практичного керівництва до реалізації проектів реструктуризації підприємства. Висновки та перспективи подальших досліджень. Запропоновані правила та сукупність відповідних моделей можна використати для розроблення інформаційної технології проектування організаційних систем із застосуванням методів імітаційного моделювання. Це дасть змогу згенерувати множину варіантів організаційних структур, визначити взаємозалежності між їнніми елементами та обрати найбільш підходящу за визначними критеріями.

\section{Ключові слова:}

реструктуризація, організаційна структура, системний підхід.

\section{USE OF THE SYSTEM APPROACH TO BUILD ORGANIZATIONAL STRUCTURE OF ENTERPRISE MANAGEMENT}

Formulation of the problem. The issues of designing the organizational structure of enterprise management in the process of its restructuring are considered. The aim of the article is to consider the essence of enterprise restructuring as one of the reasons for the need for organizational change in the company and to develop practical recommendations for applying the theory of systems analysis to build a rational organizational structure of enterprise management. The methodological basis of the study were logical methods of information processing, methods of systems analysis and modeling of systems, abstract-logical method for formulating conclusions. The basic hypothesis of research is that to build an effective organizational structure of enterprise management, you can use methods of systems analysis, including process and system approach. Exposition of basic material. The essence and reasons of necessity of structural transformations in

${ }^{1}$ Бондарєва Тетяна Іванівна, канд. екон. наук, доцент, доцент кафедри менеджменту, Національний аерокосмічний університет ім. М. С. Жуковського «Харківський авіаційний інститут», м. Харків, Україна.

Bondareva Tetyana, Ph.D in Economics, Associate professor of the Management Department, National Aerospase University «Kharkiv Aviation Institute», Kharkiv, Ukraine.

ORCID ID: 0000-0002-1834-8174

e-mail: bond_tat@ukr.net 
the organization are considered. It is revealed that the activity of any organization is influenced by the constantly changing internal and external environment. This requires the company's management to respond quickly and adapt to new operating conditions. Flexibility, adaptability, stability of the management system, as well as the consistency of the behavior of all its elements, ensuring a rational combination of centralization and decentralization of management depend on the organizational structure of enterprise management. A set of interdependent models of the enterprise management system is proposed, the use of which will allow to design an organizational structure capable of taking into account certain requirements. Originality and practical meaningfulness of research is confirmed by the possibility of using the proposed set of models as a practical tool for designing the organizational structure of any type of enterprise. The proposed developments can be used as an element of practical guidance for the implementation of enterprise restructuring projects. Conclusions and prospects of further researches. The proposed rules and a set of appropriate models can be used to develop information technology for designing organizational systems using simulation methods. This will allow you to generate a variety of options for organizational structures, determine the interdependencies between their elements and choose the most appropriate criteria.

Key words:

restructuring, organizational structure, system approach.

\section{ПРИМЕНЕНИЕ СИСТЕМНОГО ПОДХОДА ДЛЯ ПОСТРОЕНИЯ ОРГАНИЗАЦИОННОЙ СТРУКТУРЫ УПРАВЛЕНИЯ ПРЕДПРИЯТИЕМ}

Постановка проблемы. Рассмотрены вопросы проектирования организационной структуры управления предприятием в процессе его реструктуризации. Целью статьи является рассмотрение сущности реструктуризации предприятия как одной из причин необходимости организационных преобразований в компании и разработка практических рекомендаций по применению теории системного анализа для построения рациональной организационной структуры управления предприятием. Методологической основой исследования стали логические методы обработки информации, методы системного анализа и моделирования систем, абстрактно-логический метод для формулирования выводов. Основная гипотеза исследования состоит в том, что для построения эффективной организационной структуры управления предприятием можно использовать методы системного анализа, в частности процессный и системный подход. Изложение основного материала. Рассмотрены сущность и причины необходимости структурных преобразований в организации. Выявлено, что деятельность любой организации подвергается воздействию постоянно меняющейся внутренней и внешней среды. Это требует от руководства предприятия быстрого реагирования и адаптации к новым условиям функционирования. Гибкость, адаптивность, устойчивость функционирования системы управления, а также согласованность поведения всех ее элементов, обеспечение рационального сочетания централизации и децентрализации управления зависят от организационной структуры управления предприятием. Предложен комплекс взаимосвязанных моделей системы управления предприятием, использование которого позволит спроектировать организационную структуру, способную учесть перечисленные требования. Оригинальность и практическая значимость исследования подтверждается возможностью использования предложенного комплекса моделей как практического инструмента для проектирования организационной структуры предприятия любого типа. Предложенные разработки могут быть использованы как элемент практического руководства к реализации проектов реструктуризации предприятия. Выводы и перспективы дальнейших исследований. Предложенные правила и совокупность соответствующих моделей можно использовать для разработки информационной технологии проектирования организационных систем с применением методов имитационного моделирования. Это позволит сгенерировать множество вариантов организационных структур, определить взаимосвязи между их элементами и выбрать наиболее подходящую по определенным критериям.

Ключевые слова:

реструктуризация, организационная структура, системный подход.

Постановка проблеми. Сьогодні перед більшістю підприємств України постають питання виходу 3 кризового стану, досягнення фінансової стійкості, забезпечення конкурентоспроможності тощо. Вирішення питань підвищення ефективності діяльності підприємства вимагає значних зусиль, спрямованих, в першу чергу, на формування механізмів адаптації до постійно змінюваних умов зовнішнього середовища. Одним з інструментів вирішення задач адаптації до невизначених або швидко змінюваних характеристик зовнішнього середовища $є$ комплексне реформу- 
вання структури та функцій управління, тобто реструктуризація підприємства.

Необхідність реструктуризації виникає, як правило, в умовах глибокої кризи або можливості іiї настання. Іноді до реструктуризації вдаються й успішні підприємства, які швидко розвиваються та розуміють, що зростання компанії потребує відповідної зміни системи управління. Але найчастіше стимулами для проведення організаційних змін стають такі проблеми, як необхідність розширення або зміни видів діяльності, спадання обсягів виробництва або продажу, зростання невиробничих витрат, зниження рентабельності виробництва, слабкий контроль виконання робіт на підприємстві, несприятлива зміна ринкової кон'юнктури тощо. Тобто можна визначити такі можливі причини необхідності організаційних змін підприємства:

- невідповідна кваліфікація співробітників, що зумовлено низьким рівнем знань, вмінь, навичок;

- слабка взаємодія між підрозділами організації, відсутність ефективних комунікаційних каналів, що призводить до неякісних інформаційних потоків i, як наслідок, нестачі інформації для прийняття управлінських рішень;

- неефективна система розподілу ресурсів між підрозділами організації;

- неефективна система стимулювання співробітників, відсутність можливості кар'єрного та особистісного зростання, оскільки перевага надається матеріальнім стимулам;

- відсутність чіткого розуміння стратегії і цілей підприємства з боку керівників та співробітників організації, неефективна система відповідальності та контролю;

- застаріла організаційна структура, неспроможна адаптуватися до постійно змінюваного стану зовнішнього середовища організації.

Для покращення діяльності організації в таких умовах необхідно провести комплекс заходів з удосконалення технологічної, інвестиційної політики, а також організаційної структури управління підприємством, у чому і полягає процес реструктуризації.

Таким чином, під реструктуризацією будемо розуміти сукупність заходів 3 комплексного приведення умов функціонування компанії у відповідність до змінюваних умов ринку та розробленої стратегії розвитку. Ча- сто реструктуризацію пов'язують 3 комплексом заходів зі зміни організаційноструктурного статусу певних підрозділів, тобто можна говорити про створення нової організаційної структури підприємства.

Розроблення організаційної структури підприємства - це складний процес, який розвивається одночасно за трьома напрямками: склад функціональних елементів, структура та стратегічні цілі організації. На вибір та побудову організаційної структури здійснюють вплив ряд факторів, основними 3 яких $\epsilon$ функції управління, їхній склад, зміст та обсяг. Також серед факторів впливу можна назвати: масштаби виробництва, складність, характер продукції, що виготовляється, технології, науково-технічні доробки, ступінь концентрації, спеціалізації та кооперації виробництва, його розміри та територіальне розміщення.

Таким чином, актуальними є питання розроблення основних положень щодо проектування організаційної структури системи управління підприємством на основі системного підходу.

Аналіз останніх досліджень i публікацій. Для загального описання діяльності підприємства і визначення напрямків його подальшого розвитку можна використовувати системний і процесний підходи. Системний підхід підтримує вертикальну координацію різних ієрархічних контурів управління, починаючи зверху від стратегічного планування до оперативного керівництва діяльністю підприємства [1 - 3]. Процесний підхід дає можливість здійснювати горизонтальну координацію, тобто зв'язати інформаційні і матеріальні потоки підприємства, визначити ролі його співробітників у кожному процесі [4 - 6].

На практиці питання використання теоpiї систем і системного аналізу для побудови організаційних структур управління розглядались такими авторами, як Месарович М., Денисов А.О., Кондратьєв В.В., Мазур I.I., Шапиро В.Д., Бурков В.М. тощо. Однак, незважаючи на безліч наукових публікацій 3 питань розроблення організаційних структур управління підприємствами, сфера їхнього застосування при реструктуризації підприємства в умовах змінюваного внутрішнього i зовнішнього середовища залишається маловивченою.

Таким чином, метою статті $є$ розгляд сутності реструктуризації підприємства як 
однієї з причин необхідності організаційних перетворень у компанії та розроблення практичних рекомендацій щодо застосування теорії системного аналізу для побудови раціональної організаційної структури управління підприємством.

Викладення основного матеріалу дослідження. У сучасних складних ринкових умовах багато успішних компаній стикаються з проблемою занадто ускладненої організаційної структури. Впроваджуючи інновації задля найбільш повного задоволення потреб споживачів, виходячи на нові конкуренті ринки 3 більш жорстким конкурентним середовищем, беручи участь у процесах інтеграції або поглинання, компанії часто створюють нові бізнес-одиниці, підрозділи, рівні управлінської ієрархії або додаткові зв'язки в системі підпорядкування. Як кінцевий результат формується матрична організаційна структура, що поєднує в собі як мінімум два ланцюжка підпорядкування. Окрім нівелювання основного принципу менеджменту - єдиноначальності, ці структури, як правило, є занадто складними, що негативно впливає на їхню ефективність.

Багато компаній намагаються удосконалити організаційну структуру i знизити витрати шляхом скорочення штатів, складанням інших схем рівнів управлінської ієрархії тоді, коли необхідним було б створення нової, більш ефективної організаційної структури управління підприємством [7].

У загальному випадку під організаційною структурою підприємства будемо розуміти певну структурну схему, яка $\epsilon$ основою для розподілу функцій серед співробітників. Іншими словами, структура організації - це елемент внутрішнього середовища, зокрема склад і співвідношення іiі внутрішніх ланок.

Під організаційною структурою управління розуміють частину загальної структури організації, яка здійснює функції управління [8].

Побудова організаційної структури здійснюється 3 метою встановлення чітких взаємозв'язків між структурними підрозділами підприємства, розподілу між ними прав, функцій, обов'язків і відповідальності, забезпечення узгодженості між структурними одиницями.

Процес формування організаційної структури включає [9]:
1. Поділ організації за найважливішими напрямками діяльності в реалізації стратегії, визначення видів діяльності лінійних і штабних підрозділів.

2. Установлення співвідношень повноважень різних посад, поділ на більш мілкі підрозділи 3 метою використання спеціалізації.

3. Визначення посадових обов'язків як сукупності певних задач і функцій, а також покладання їх на конкретних осіб.

При цьому успішні організації регулярно здійснюють оцінювання ступеня адекватності та ефективності своїх організаційних структур та змінюють їх у разі необхідності.

Побудова організаційних структур управління здійснюється 3 урахуванням таких принципів [10]:

- відповідність структури управління цілям бізнесу;

- єдність структури і функції управління;

- первинність функції і вторинність органу управління;

- раціональне поєднання в структурі управління централізації, спеціалізації та інтеграції функцій управління;

- співвідносність структури управління 3 виробничою і організаційною структурами підприємства;

- комплексна ув'язка в структурі управління всіх видів діяльності;

- відповідність системи збору та обробки інформації організаційній структурі управління.

- мінімальна кількість рівнів управління і найкоротші ланцюги команд.

У менеджменті як процеси частіше за все розглядають такі [9]: адміністративні процеси управління, процеси обміну інформацією, матеріальні процеси, які перетворюють ресурси на продукти i послуги. 3 об'єктом управління частіше за все пов'язують процеси 3 перетворення матеріальних потоків, а 3 системою управління адміністративні і інформаційні процеси реалізації процедур менеджменту. Також розуміють, що процес або група процесів описують реалізацію певної функції управління або діяльності підприємства.

Проектування нової системи управління підприємства пов'язано зі створенням у структурі підприємства певних підрозділів, розробкою відповідних структурних рішень, стандартних процедур і регламентів. Це при- 
зводить до додаткових фінансових витрат як на проведення організаційних змін, так і на підтримку ефективного функціонування системи управління підприємства.

Виходячи 3 перерахованих вище завдань і складності системи управління підприємства, всі її властивості неможливо відразу описати повно й достовірно однією моделлю. Тому необхідно розробити комплекс взаємозалежних моделей системи управління підприємства, які характеризують різні аспекти діяльності і поводження системи.

Для визначення складу й послідовності побудови моделей системи управління підприємства розглянемо технологію організаційного моделювання, що містить такі основні етапи [4]:

1. Моделювання структури.

На цьому етапі спочатку формують функціональну модель, що описує склад функцій підрозділів і відповідає на запитання Що? Потім формують модель організаційної структури, яка описує склад структурних елементів підрозділів, тобто дає відповідь на запитання Хто? Між цими моделями будують матричну проекцію (Що? Хто?), яка встановлює відповідальність структурних елементів за виконання певних функцій підрозділу. Це дозволяє розробити положення про підрозділ і посадові інструкції його співробітників.

2. Моделювання процесів.

На цьому етапі на основі функціональної моделі формують процесну модель (Що? Як?), яка описує послідовність робіт для реалізації функцій підрозділу. Паралельно на основі моделі організаційної структури формують рольову модель (Хто? Кому?), що описує роль структурних елементів у процесах підприємства. Між цими моделями будують матричну проекцію (Що? Як? Хто? Кому?), яка показує рольову взаємодію структурних елементів і їхню відповідальність при виконанні процесів підрозділу. Це дозволяє розробити необхідну організаційнорозпорядницьку документацію підрозділу i регламенти виконання його процедур.

3. Моделювання програми дій.

На цьому етапі переходять до кількісного опису процесів підрозділу. Встановлюють строки виконання робіт і формують план дій підрозділу на певний часовий період (Що? Хто? Як? Кому? Коли?). Також визначають необхідні для виконання робіт ресурси i формують бюджет підрозділу на плановий період (Що? Хто? Як? Кому? Коли? Скільки?).

Таким чином, використовуючи принцип багаторівневого подання складних систем і технологію організаційного моделювання для опису системи управління підприємства можна побудувати наступні моделі по кожному структурному підрозділу:

1. Структурні моделі, до яких будемо відносити:

- цільову модель (Навіщо?), що містить склад цілей підрозділу;

- функціональну модель (Що?), яка містить склад функцій, необхідних для досягнення цілей підрозділу;

- модель організаційної структури (Хто?), яка містить склад структурних елементів, необхідних для виконання функцій підрозділу.

2. Процесну модель (Як?), що показує послідовність робіт для реалізації функцій підрозділу.

Для встановлення взаємозв'язку між моделями системи управління підприємства введемо такі матричні проекції:

1. Матрична проекція між цільовою й функціональною моделями (Навіщо? Що?), яка встановлює відповідність функцій цілям. Як вихідні дані для формування матричної проекції між цільовою й функціональною моделями підрозділу підприємства будемо використовувати: склад цілей підрозділу; склад функцій, необхідних для досягнення цілей підрозділу; закріплення функцій за цілями підрозділу.

За допомогою матричної проекції між цільовою й функціональною моделями можна проводити функціональний аналіз системи управління за такими напрямками:

- чи за всіма цілями закріплені функції підрозділу;

- чи необхідно розширити склад функції підрозділу;

- виконання скількох функцій необхідно для досягнення кожної мети функціонування підрозділу;

- чи достатньо функцій, закріплених за певною метою підрозділу;

- чи є зайві функції, закріплені за певною метою;

- чи відповідають функції, закріплені за певною метою, можливості ії досягнення.

2. Матрична проекція між функціональною моделлю й моделлю організаційної структури (Що? Хто?), яка встановлює 
відповідальність структурних елементів за виконання функцій. Як вихідні дані для формування матричної проекції між функціональною моделлю й моделлю організаційної структури системи управління підприємства будемо використовувати: склад функцій підрозділу підприємства; склад структурних елементів (посад), необхідних для виконання функцій; закріплення структурних елементів (посад) за функціями.

За допомогою матричної проекції між функціональною моделлю й моделлю організаційної структури можна проводити структурно-функціональний аналіз системи управління підприємства за такими напрямками:

- чи за всіма функціями підрозділу закріплені структурні елементи;

- чи необхідні додаткові структурні елементи для виконання функцій підрозділу;

- чи є зайві структурні елементи, що не беруть участь у виконанні функцій;

- яка завантаженість структурних елементів, що беруть участь у виконанні функцій.

Крім цього матрична проекція між функціональною моделлю й моделлю організаційної структури дозволяє розробити положення про підрозділ підприємства, що містить склад цілей, функцій, структурних елементів, закріплення функцій за структурними елементами, а також посадові інструкції співробітників підрозділу.

3. Матрична проекція між функціональною й процесною моделями (Що? Як?), яка встановлюе відповідність процесів функціям. Як вихідні дані для формування матричної проекції між функціональною й процесною моделями підрозділу підприємства будемо використовувати: склад функцій структурного підрозділу; склад процесів, які реалізують виконання функцій; закріплення процесів за функціями.

За допомогою матричної проекції між функціональною й процесною моделями можна проводити аналіз процесів структурних підрозділів системи управління підприємства за такими напрямками:

- чи за всіма функціями закріплені процеси;

- чи необхідні додаткові процеси для реалізації функцій підрозділу;

- чи є зайві процеси, що не беруть участь у реалізації функцій; скільки процесів бере участь у реалізації кожної функції і яка їхня взаємодія;

чи відповідають процеси, закріплені за певною функцією, цілі іï реалізації.

За допомогою матричної проекції між функціональною моделлю й моделлю організаційної структури можна проводити структурно-функціональний аналіз системи управління підприємства за такими напрямками:

- $\quad$ чи за всіма функціями підрозділу закріплені структурні елементи;

- $\quad$ чи необхідні додаткові структурні елементи для виконання функції;

- чи є зайві структурні елементи, що не беруть участь у виконанні функцій;

- яка завантаженість структурних елементів, що беруть участь у виконанні функцій.

3. Матрична проекція між функціональною й процесною моделями (Хто? Як?), що встановлює відповідальність структурних елементів при виконання процесів. Як вихідні дані для формування матричної проекції будемо використовувати: склад функцій структурного підрозділу підприємства; склад процесів, які реалізують виконання функцій; закріплення процесів за функціями.

За допомогою матричної проекції між функціональною й процесною моделями можна проводити аналіз процесів системи управління підприємства за такими напрямками: чи за всіма функціями підрозділу підприємства закріплені процеси; чи необхідні додаткові процеси для реалізації функцій; чи є зайві процеси, що не беруть участь у реалізації функцій; скільки процесів бере участь у реалізації кожної функції і яка їхня взаємодія; чи відповідають процеси, закріплені за певною функцією, цілі іiі peалізації.

За допомогою запропонованих вище правил для типового підрозділу підприємства можна побудувати такі матричні проекції між моделями елементів системи управління підприємства на всіх рівнях ієрархії.

Висновки та перспективи подальших досліджень. Таким чином, для забезпечення необхідної повноти, точності й однаковості опису різних аспектів управління підприємством слід сформувати комплекс взаємозалежних моделей системи управління. За допомогою таких моделей можна вирішувати такі завдання: 
- проводити

функціональний аналіз різних варіантів організаційних структур;

- вибирати найкращі варіанти побудови нової або вдосконалення існуючої організаційної структури управління підприємством;

- розробляти необхідну організаційнорозпорядницьку документацію, іiі положення, регламенти й посадові інструкції;

- забезпечувати автоматизоване виконання основних функцій управління підприємства.

Як напрямок подальших досліджень можна рекомендувати на базі запропонованих правил побудови та сукупності моделей системи управління підприємством розробити інформаційну технологію проектування організаційних систем із застосуванням методів імітаційного моделювання. Це дасть змогу згенерувати множину варіантів організаційної структури, визначити взаємозалежності між їі елементами та обрати найбільш підходящу за визначними критеріями.

\section{Література}

1. Месарович М., Мако Д., Такахара И. Теория иерархических многоуровневых систем. Москва: Мир, 1973. 344 с.

2. Мессарович М. Такахара И. Общая теория систем. Математические основы. Москва: Мир, 1978. 312 с.

3. Денисов А. А., Колесников Д. Н. Теория больших систем управления. Ленинград: Энергоиздат, 1982. 288 с.

4. Кондратьев В. В., Краснова В. Б. Реструктуризаџия управления компанией: 17 модульная программа для менеджеров. Модуль 6. Москва: ИнфраМ, 2000. 240 с.

5. Мазур И. И., Шапиро В. Д. Реструктуризация предприятий и компаний. Москва: Высшая школа, 2000. 587 с.

6. Бурков В. Н., Ириков В. А. Модели и методы управления организачионными системами. Москва: Наука, 1994. 234 с.

Стаття надійшла

до редакції : 05.11.2020 p.
7. Базилевич Л. А. Моделирование организационных структур: підруч. Ленинград: ЛГУ, 1978. 159 с.

8. Франчук В. И. Основы построения организационных систем. Москва: Экономика, 1991. $111 \mathrm{c.}$

9. Басовский Л. Е. Менеджмент: учебное пособие. Москва: ИНФРАМ, 2007. $216 \mathrm{c}$.

10. Грибов, В. Д. Менеджмент: учебное пособие. Москва: КНОРУС, 2007. 280 с.

\section{References}

1. Mesarovich, M., Mako, D. and Takahara, I. (1973). Theory of hierarchical multilevel systems. Moscow: Mir, 344.

2. Messarovich, M., Takahara, I. (1978). General theory of systems. Mathematical foundations. Moscow: Mir, 312.

3. Denisov, A. A., Kolesnikov, D. N. (1982). Theory of large control systems. Leningrad: Energoizdat, 288.

4. Kondratyev, V. V., Krasnova, V. B. (2000). Restructuring of company management: 17 modular program for managers. Module 6. Moscow: InfraM, 240.

5. Mazur, I. I., Shapiro, V. D. (2000). Restructuring of enterprises and companies. Moscow: Higher school, 587.

6. Burkov, V. N., Irikov, V. A. (1994). Models and methods of management of organizational systems. Moscow: Nauka, 234.

7. Bazilevich, L. A. (1978). Modeling of organizational structures. Leningrad: Leningrad State University, 159.

8. Franchuk, V. I. (1991). Basics of building organizational systems. Moscow: Economics, 111.

9. Basovsky, L. E. (2007). Management: a tutorial. Moscow: INFRAM, 216.

10. Gribov, V. D. (2007). Management: textbook. Moscow: KNORUS, 280 p.

\section{Стаття прийнята}

до друку: 28.12.2020 p.

Бібліографічний опис для цитування :

Бондарєва Т. І. Застосування системного підходу для побудови організаційної структури управління підприємством / Т. І. Бондарєва // Часопис економічних реформ. - 2020. - № 4 (40). - C. 85-91. 